\title{
Surface Water Sediments Characterization Using Metallic Trace Elements (MTEs): Case of the Artisanal Gold Mining Sites of Kokumbo (Côte d'Ivoire)
}

\author{
Kouassi Ernest Ahoussi ${ }^{*}$, Armand Patrick Yapo', Amani Michel Kouassi², Yao Blaise Koffi ${ }^{1}$ \\ ${ }^{1}$ Training and Research Unit of Earth Sciences and Mining Resources (Laboratory of Soil, Water and Geomaterial Sciences) \\ Universiyé Félix Houphouët Boigny Cocody, Abidjan, Côte d'Ivoire \\ ${ }^{2}$ Department of Earth Sciences and Mining Resources, Institute National Polytechnique Félix Houphouët Boigny (INP-HB), \\ Yamoussoukro, Côte d'Ivoire \\ Email: *akouassiernest@gmail.com
}

How to cite this paper: Ahoussi, K.E., Yapo, A.P., Kouassi, A.M. and Koffi, Y.B. (2020) Surface Water Sediments Characterization Using Metallic Trace Elements (MTEs): Case of the Artisanal Gold Mining Sites of Kokumbo (Côte d'Ivoire). Journal of Environmental Protection, 11, 649-663. https://doi.org/10.4236/jep.2020.119039

Received: April 14, 2020

Accepted: August 31, 2020

Published: September 3, 2020

Copyright (๑) 2020 by author(s) and Scientific Research Publishing Inc. This work is licensed under the Creative Commons Attribution International License (CC BY 4.0).

http://creativecommons.org/licenses/by/4.0/ (c) (i) Open Access

\begin{abstract}
The main purpose of this study is to characterize the surface sediments of the Kokumbo artisanal gold mining sites in Metallic trace Elements (MTEs). A total of 12 samples of surface water sediments were collected for this study. The samples were analyzed using the Atomic Absorption Spectrophotometer (AAS). The mean concentrations of $\mathrm{Mn}(611.37 \mathrm{mg} / \mathrm{kg})$ and $\mathrm{Zn}(955.86$ $\mathrm{mg} / \mathrm{kg}$ ) in the sediments were very high compared to the standard in unpolluted sediments. The enrichment factor (EF) shows that there is an enrichment of $\mathrm{Mn}$ at some sites ( $\mathrm{EF}(\mathrm{Mn})>2$ ). The presence of $\mathrm{As}, \mathrm{Mn}$, and $\mathrm{Zn}$ is also highlighted by the geo-accumulation index (I-geo) which shows slight pollution in $\mathrm{Mn}(0<\mathrm{I}$-geo $(\mathrm{Mn})<1)$ on some sites. Moderate pollution for As $(1<\mathrm{I}$-geo $(\mathrm{As})<2)$ was determined at the treatment site and high pollution in $\mathrm{Zn}$ at some sites in the area (I-geo $(\mathrm{Zn})>3$ ). This study shows that the presence of $\mathrm{Zn}$ in the sediments is linked to artisanal gold mining activities. Indeed, $\mathrm{Zn}$ is much used for gold recovery. The statistical analysis (PCA) shows, on the one hand, natural mineralization of the sediments and addition of metals linked to anthropic activities corresponding to the erosion of mining discharges. The surface sediments of the Kokumbo mining sites show pollution in As, Mn, and Zn.
\end{abstract}

\section{Keywords}

Artisanal Mining, Enrichment Factor (EF), MTEs, Pollution, Sediment 


\section{Introduction}

Throughout the world, mining generally damages the environment by inevitably causing the degradation of the biosphere. In Côte d'Ivoire, artisanal gold mining is increasingly important as it contributes to improving the income of rural populations income. The gold mines in operation or abandoned without any rehabilitation are certainly sources of contamination and environmental damage.

According to [1], mining activities are considered as fundamental source of heavy metals in the environment. Besides, the use of chemical substances (mercury, cyanide, hydrochloric acid, and sulphuric acid) can reduce soil fertility and even contaminate and reduce the quality of water resources [2]. These extraction and mining operations and the disposal of mine wastes, if not controlled, are obvious sources of environmental contamination, particularly of surface sediments.

As a result of the socio-political crises and economic difficulties encountered by farmers in the country in recent decades, several gold mining strategies have been implemented by the population to cope with the situation. In Côte d'Ivoire, more than 1000 clandestine gold panning sites exist in the country and nearly 500,000 people rely on this activity. Indeed, in response to the expansion of illegal and clandestine gold panning, Ivorian government has adopted a three-year national program (2014-2016) for the rationalization of artisanal mining [3] to clean up, organize and supervise the activity. In gold panning sites, some tailings that remain in the open air can impact the environment and constitute a potential risk for the inhabitants of mining regions. These tailings are often very rich in residual metal ores, iron sulfides, and mineral phases containing toxic MTEs. Most of the important research work on gold mining activities has been carried out on groundwater in the Hiré regions [4] [5], and on the environmental assessment of gold panning. Also, [6] worked on the impacts of the former SOMIAF (Société des Mines d'AFEMA) mine on surface sediments. For example, [7] assessed the effect of artisanal mining on the pollution levels of certain trace elements in sediments and water in Ghana. However, no studies have been carried out on the characterization of surface sediment contamination in a gold panning area in our country. It is in this perspective that this work was carried out, on the one hand, to determine the level of contamination of surface sediments from their content of MTEs and on the other hand to identify the sources of contamination of the sediments of Kokumbo taking into account the climate and the geological context in the region. This study aims not only at the preserving of sediments but also at the protecting the environment and population health.

\section{Materials and Methods}

\subsection{Study Area}

Kokumbo is located in the center of Côte d'Ivoire in the department of Toumo$\mathrm{di}$, in the ram region (Lakes District). It lies between latitudes $6^{\circ} 19^{\prime}$ and $6^{\circ} 34^{\prime} \mathrm{N}$ 
and longitudes $5^{\circ} 06^{\prime}$ and $5^{\circ} 20^{\prime} \mathrm{W}$ and is a sub-prefecture chief town comprising 5 villages: Kpléssou, Niamkey-Konankro, Kokumbo, Akroukro and Kimoukro (Figure 1). Its surface area is $330 \mathrm{~km}^{2}$ and its population is estimated at 24,650 inhabitants [8]. The region is located in the Baoulean climate. It is a humid climate, common to the dense forest zone [9]. It is characterized by two rainy seasons separated by two dry seasons. Rainfall averages $1092 \mathrm{~mm}$ per year. The major rainy season is from March to June and the minor one from September to October. The big dry season is from November to February and the small one from July to August. The average annual temperature is around $27^{\circ} \mathrm{C}$.

The relief is more or less uneven with plains and plateaus that are not very pronounced and belonged to the "baoule chain". It is dominated to the East by Mount Alebouma (449 m) and to the West by Mount Kokumbo (510 m). The Bandama River waters the West of the sub-prefecture from the village of $\mathrm{Ki}$ moukro. Several rivers (Bronzoué, Kpléssou and Kpossou) exist in the locality. The soil of the region is based on vast granitic massifs, metamorphic rocks and schist [10] and belongs to the Baoulé-Mossi domain of the West African craton. The rocks encountered generally consist of granitoid, green rocks, volcano-sedimentary rocks, and shales (Figure 2). Two types of aquifers are encountered (alteration and fractures) [11] [12]. The presence of schistosity, fractures, and large quartz veins favors infiltration and also groundwater recharge [13].

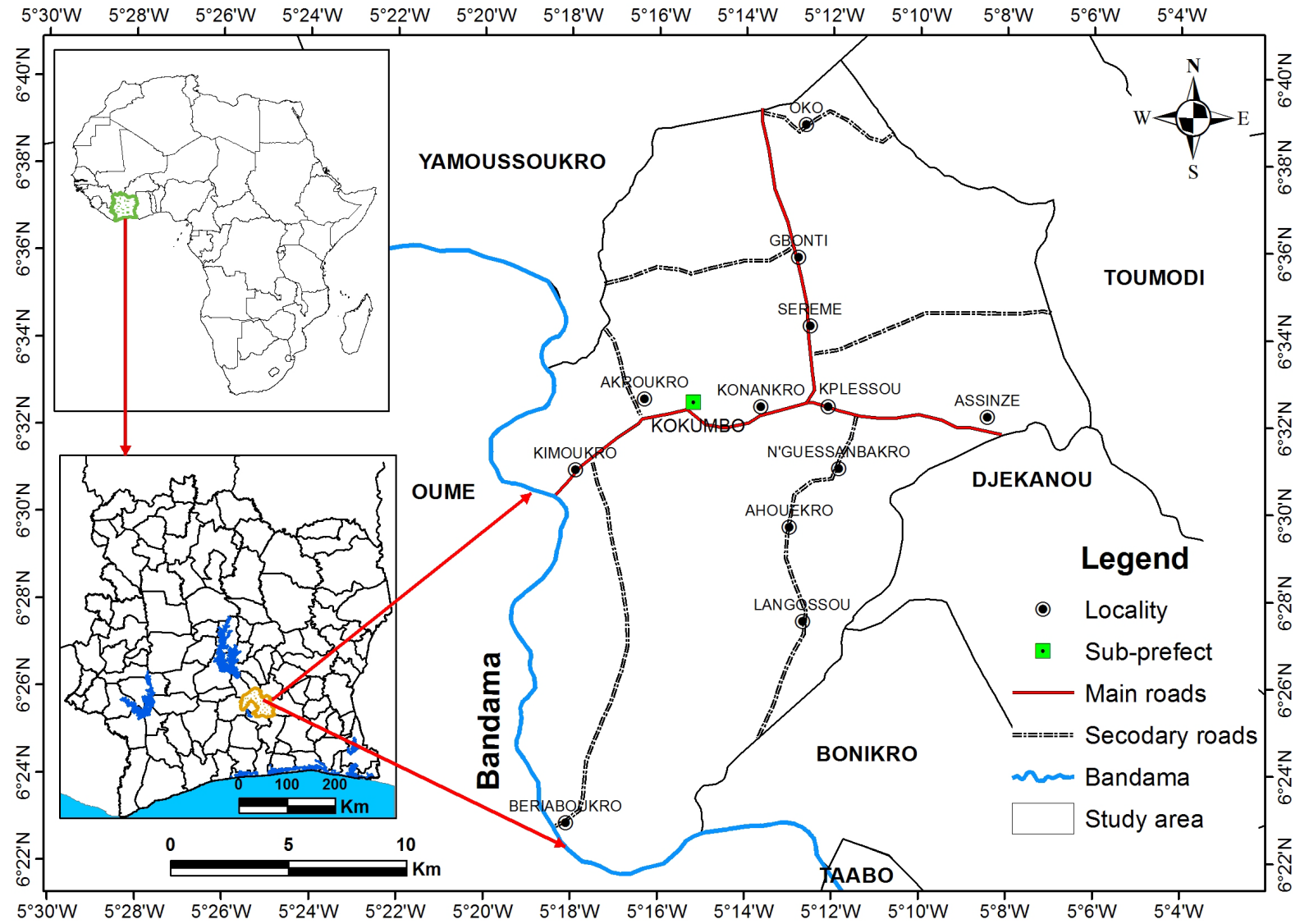

Figure 1. Location of the study area. 


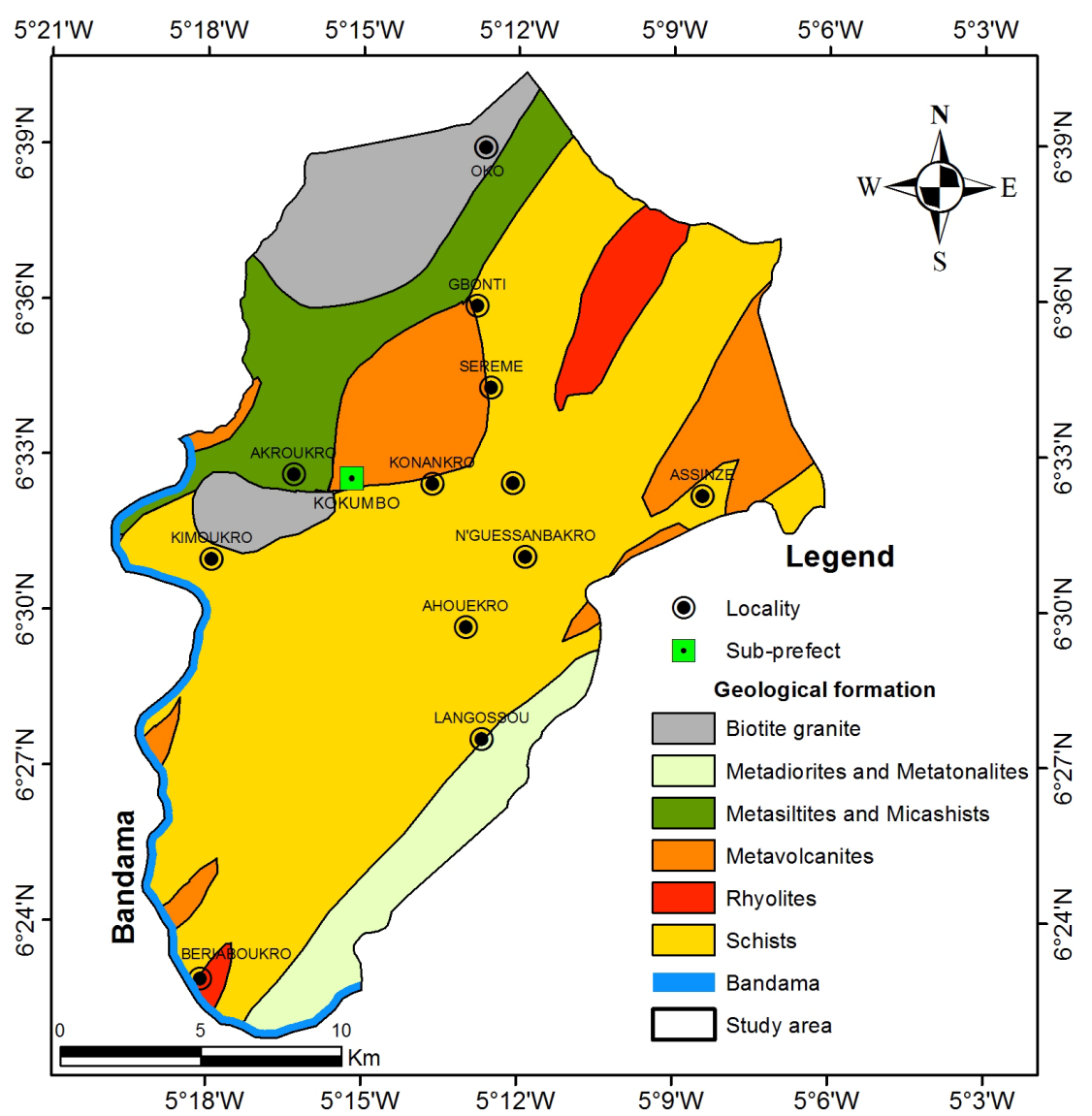

Figure 2. Geological map of the study area.

\subsection{Methods}

\subsubsection{Sampling and Analysis Method}

For the exploitation of the collected data, several computer tools were used. The STATISTICA software was used for the application of Principal Component Analysis (PCA) and the ArcGIS software was used to produce the various maps.

A sampling campaign took place during the rainy season (June 2018) during which 12 surface sediment samples were taken. Thus we had 7 samples on the artisanal gold mining sites (P1, P2, and P3) and (P8, P9, P10) which are cyanidation sites. Site P12 is an ore processing site. Also, we took 2 samples P4 and P5 on a stream (bronzed river) and a sample P11 on the Kpossou river. The 2 samples P6 and P7 were taken from the Bandama River. It should be noted that site P6 is near a gold panning site (washing ramp) and P7 is near the SODECI treatment plant serving the sub-prefecture in drinking water (Figure 3). Sediment sampling was carried out at the same time as surface water sampling at the same sites in the gold mines (extraction and treatment) of Kokumbo and the surrounding waterways. An amount of $200 \mathrm{~g}$ was collected about $10 \mathrm{~cm}$ from the water/sediment interface. The samples were stored at $-18^{\circ} \mathrm{C}$ and then sent to the laboratory. The determination of the content of TME in the various sediment samples (As, Cd, Cr, Fe, Mn, Ni, Pb, and $\mathrm{Zn}$ ) was carried out by the ICP-AAS (Inductively Coupled Plasma Atomic Absorption Spectrometer) method. 


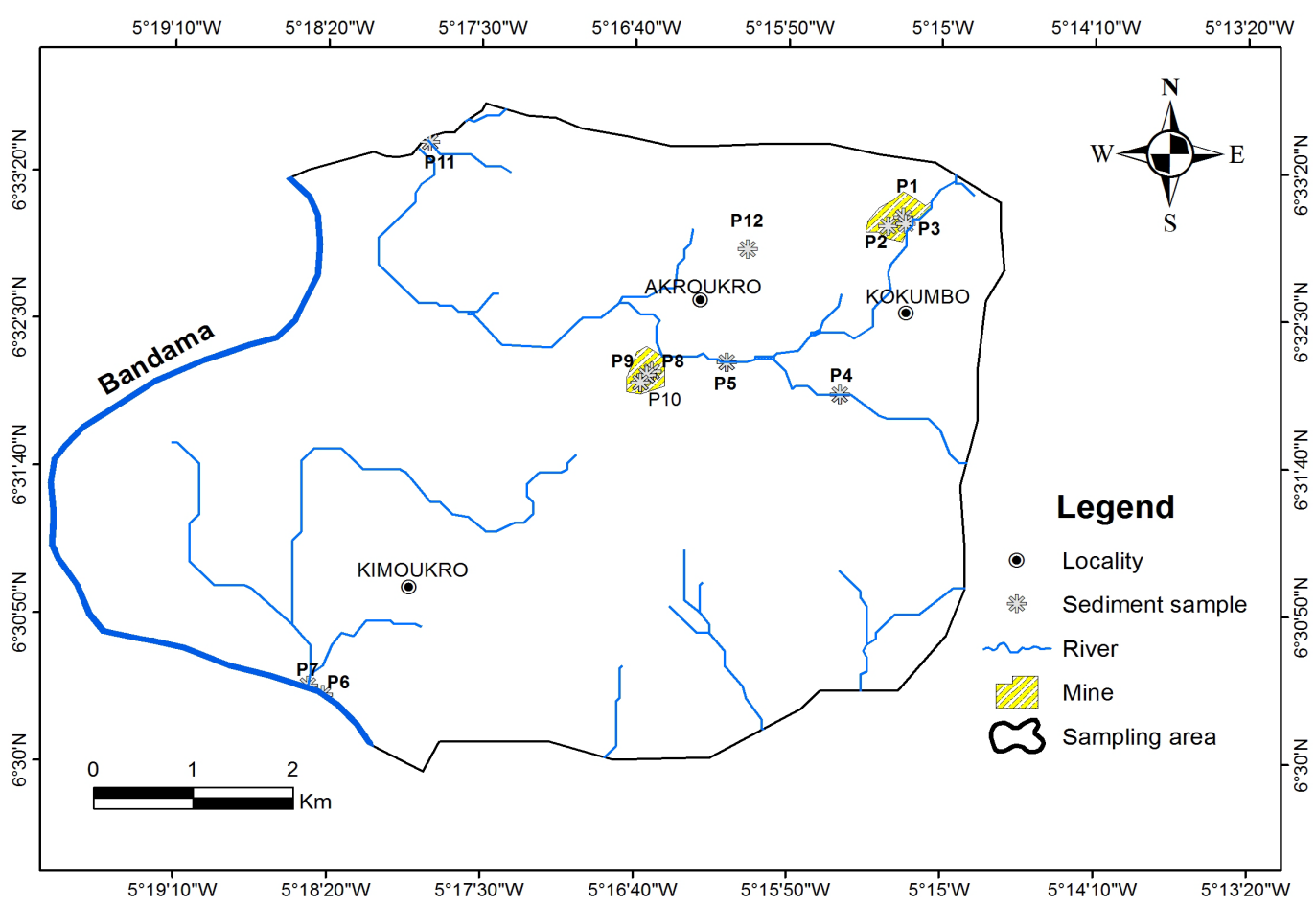

Figure 3. Map of sampling points.

\subsubsection{Method for Estimating Sediment Contamination Intensity}

Two (2) indices were used to assess sediment pollution. These are the Enrichment Factor (EF) and the Geo-accumulation Index (I-geo).

\section{1) Enrichment Factor $E F$}

To determine the anthropogenic or natural origin of the elements, the enrichment factor (EF) is calculated (Equation (1)). The reference element must come from a natural terrigenous source and be selected from the elements $\mathrm{Al}, \mathrm{Li}$, Sc, $\mathrm{Zr}, \mathrm{Ti}$, Th, or sometimes Fe or Mn [14]. The reference element chosen for this study is iron $(\mathrm{Fe})$ because of its natural abundance in the environment. This factor is defined as follows:

$$
\mathrm{FE}=([\mathrm{M}] \mathrm{ech} /[\mathrm{X}] \mathrm{ech}) /([\mathrm{M}] \mathrm{réf} /[\mathrm{X}] \text { réf })
$$

$\mathrm{EF}=$ enrichment factor; $[\mathrm{M}] \mathrm{ech}=$ concentration of metal $\mathrm{M}$ in the sample; $[\mathrm{X}]$ ech $=$ concentration of the reference element in the sample; $[\mathrm{M}] \mathrm{ref}=$ concentration of metal $\mathrm{M}$ in the reference material; $[\mathrm{X}] \mathrm{ref}$ = concentration of the reference element in the reference material. Depending on the value of the EF we have:

$\mathrm{EF}<2$ no enrichment or minimal enrichment; $2 \leq \mathrm{EF}<5$ moderate enrichment; $5 \leq \mathrm{EF}<20$ significant enrichment; $20 \leq \mathrm{EF}<40$ very high enrichment; $\mathrm{EF} \geq 40$ extreme enrichment [15].

If the $\mathrm{EF}$ is equal to or may differ from 1, the element is mainly of terrigenenous origin. If $\mathrm{EF}>1.5$ then there are other sources than the natural terrigenenous source, in this case, the anthropogenic source. According to [16], EF is calculated from the concentration of trace elements in the continental crust (UCC: Upper Continental Crust) (Table 1 \& Table 2). 
Table 1. The concentration of trace elements in the continental crust.

\begin{tabular}{ccccccccc}
\hline MTEs & As & Cd & Cr & Fe & Mn & Ni & Pb & Zn \\
\hline UCC $(\mathrm{mg} / \mathrm{kg})$ & 2 & 0.102 & 35 & 30,890 & 527 & 18.6 & 17 & 52 \\
\hline
\end{tabular}

Table 2. The concentration of MTEs in unpolluted sediment.

\begin{tabular}{ccccccccc}
\hline & As & $\mathrm{Cd}$ & $\mathrm{Cr}$ & $\mathrm{Fe}$ & $\mathrm{Mn}$ & $\mathrm{Ni}$ & $\mathrm{Pb}$ & $\mathrm{Zn}$ \\
\hline Persaud and al. (1993) & 4.2 & 1.1 & 31 & 31,200 & 400 & 31 & 23 & 65 \\
Calamari and Naeve, (1994) & 5.2 & 0.11 & - & 41,000 & 770 & - & 19 & 95 \\
\hline
\end{tabular}

\section{2) Geo-accumulation index (I-geo)}

The second criterion for assessing the intensity of metal pollution is the geo-accumulation index (Equation (2)). This empirical index compares a given concentration against a value considered as geochemical background [17].

$$
\text { I-geo }=\log _{2}\left(\frac{C_{n}}{1.5 \times B_{n}}\right)
$$

I-geo $=$ Geo-accumulation index; $\log _{2}=\log$ base $2 ; n=$ element under consideration; $C=$ measured concentration in the sample; $B_{n}=$ geochemical background; 1.5 = geochemical background exaggeration factor.

The geo-accumulation index is composed of 7 grades or classes; I-geo $<0$ no pollution; $0<$ I-geo $>1$ no to light pollution; $1<$ I-geo $>2$ moderate pollution; 2 $<$ I-geo $>3$ moderate to heavy pollution; $3<$ I-geo $>4$ heavy pollution; $4<$ I-geo $>5$ heavy to extreme pollution; I-geo $>5$ extreme pollution [17].

\subsubsection{Principal Component Analysis (PCA) Method}

This study is intended to reduce the number of statistical parameters and find correlation coefficients between the parameters studied. For this purpose, the Principal Component Analysis (PCA) was used.

The PCA was conducted to highlight hydrochemical similarities between different surficial sediments to extract representative variables [18] [19] [20]. Eight (8) variables were used in this study: As, $\mathrm{Cd}, \mathrm{Cr}, \mathrm{Fe}, \mathrm{Mn}, \mathrm{Ni}, \mathrm{Pb}$, and $\mathrm{Zn}$.

\section{Results}

\subsection{Metallic Characteristics in Surface Sediments}

The concentrations of MTEs in sediments in the study area are presented in the following table (Table 3).

Analysis of this table shows that the concentration of arsenic in sediment ranges from 0.11 to $8.97 \mathrm{mg} / \mathrm{kg}$, with an average of $1.21 \mathrm{mg} / \mathrm{kg}$. At all sites, the sediment concentration of cadmium is less than $0.01 \mathrm{mg} / \mathrm{kg}$. For chromium, concentrations range from 1.08 to $20.76 \mathrm{mg} / \mathrm{kg}$, with an average of $6.35 \mathrm{mg} / \mathrm{kg}$. Iron is the most abundant metallic element in the sediments. Concentrations vary from 897 to $99,451 \mathrm{mg} / \mathrm{kg}$, with an average of $20,583.18 \mathrm{mg} / \mathrm{kg}$.

Manganese concentrations range from 12.89 to $1754.1 \mathrm{mg} / \mathrm{kg}$, with an average 
Table 3. Concentrations of MTEs in sediment ( $\mathrm{mg} / \mathrm{kg})$.

\begin{tabular}{|c|c|c|c|c|c|c|c|c|}
\hline \multirow{2}{*}{ Sampling area- } & \multicolumn{8}{|c|}{ Metal (mg/kg) } \\
\hline & As & $\mathrm{Cd}$ & $\mathrm{Cr}$ & $\mathrm{Fe}$ & $\mathrm{Mn}$ & $\mathrm{Ni}$ & $\mathrm{Pb}$ & $\mathrm{Zn}$ \\
\hline $\mathrm{P} 1$ & 0.15 & 0.001 & 9.19 & 9089 & 198.9 & 8.36 & 2.86 & 13.43 \\
\hline $\mathrm{P} 2$ & 0.87 & 0.001 & 1.57 & 897 & 65.89 & 6.74 & 0.84 & 0.61 \\
\hline P3 & 0.36 & 0.00 & 13.92 & 75,370 & 890 & 3.51 & 18.94 & 9081 \\
\hline $\mathrm{P} 4$ & 0.60 & 0.00 & 2.97 & 9560 & 308 & 0.23 & 6.71 & 821 \\
\hline P5 & 0.26 & 0.001 & 9.67 & 9989 & 1754.1 & 8.68 & 3.74 & 14.39 \\
\hline P6 & 0.58 & 0.001 & 2.08 & 7651 & 678.8 & 5.49 & 4.17 & 89.21 \\
\hline P7 & 0.11 & 0.001 & 7.92 & 13,370 & 892 & 0.71 & 1.34 & 781 \\
\hline P8 & 0.30 & 0.00 & 1.97 & 5560 & 808 & 0.11 & 7.30 & 421 \\
\hline P9 & 0.54 & 0.001 & 1.08 & 99,451 & 678.8 & 7.84 & 3.14 & 37.10 \\
\hline $\mathrm{P} 10$ & 0.87 & 0.001 & 1.90 & 997 & 12.89 & 3.95 & 0.94 & 78.01 \\
\hline P11 & 0.95 & 0.001 & 3.20 & 9075 & 778.9 & 9.47 & 4.97 & 34.29 \\
\hline $\mathrm{P} 12$ & 8.97 & 0.001 & 20.76 & 5989 & 270.19 & 6.93 & 0.22 & 99.31 \\
\hline Minimum & 0.11 & 0.00 & 1.08 & 897 & 12.89 & 0.11 & 0.22 & 0.61 \\
\hline Maximum & 8.97 & 0.001 & 20.76 & 99,451 & 1754.1 & 9.47 & 18.94 & 9081 \\
\hline Average & 1.21 & 0.00 & 6.35 & $20,583.2$ & 611.37 & 5.17 & 4.6 & 955.86 \\
\hline $\mathrm{SD}^{\mathrm{a}}$ & 2.46 & 0.00 & 6.15 & $31,836.4$ & 483.58 & 3.41 & 5.05 & 2575.91 \\
\hline
\end{tabular}

aStandard Deviation.

of $611.37 \mathrm{mg} / \mathrm{kg}$. Nickel is weakly present in the sediments, with a content between 0.11 and $9.47 \mathrm{mg} / \mathrm{kg}$, with an average of $5.17 \mathrm{mg} / \mathrm{kg}$. Lead is also present to a small extent in the sediments. Concentrations range from 0.22 to 18.94 $\mathrm{mg} / \mathrm{kg}$, with an average of $4.6 \mathrm{mg} / \mathrm{kg}$. Zinc concentrations are significant in sediments. They range from 0.61 to $9081 \mathrm{mg} / \mathrm{kg}$, with an average of $955.86 \mathrm{mg} / \mathrm{kg}$.

The distribution of the TMEs in the mines is as follows: $\mathrm{Fe}>\mathrm{Zn}>\mathrm{Mn}>\mathrm{Cr}>$ $\mathrm{Ni}>\mathrm{Pb}>\mathrm{As}>\mathrm{Cd}$. Indeed, Fe remains the element most present in the sediments, followed by $\mathrm{Zn}$, which is much used in the treatment of gold.

\subsection{Assessment of the Level of Surface Sediment Contamination}

\subsubsection{Enrichment Factor (EF)}

The enrichment factor (EF) calculated from the chemical analysis data is presented in the table below (Table 4).

This table shows that As has an EF that ranges from 0.10 to 23.10, with an average of 4.77. The EF $<2$ for most of the sampled points indicates that this element is not enriched at all sampling sites, except for P2, P10, and P12 where $(E F>10)$. This shows significant enrichment at these sites related to gold panning activity. In the study area, Cd enrichment was observed at all the points studied. Cr enrichment is low at almost all sampling sites, with $\mathrm{EF}<2$. However, at sites $\mathrm{P} 2, \mathrm{P} 10$, and $\mathrm{P} 12(\mathrm{EF}>1.5)$ its presence is due to gold panning activity. On-site $\mathrm{P} 12$ there is moderate enrichment $(2 \leq \mathrm{EF}<5)$. Its presence is related to gold panning activity. At the Mn level, enrichment is observed on sites P1, P3, $\mathrm{P} 4, \mathrm{P} 9, \mathrm{P} 10$, and $\mathrm{P} 12$, with $\mathrm{EF}<2$. It is moderately to significantly enriched on sites P2, P5, P6, P7, P8 and P11 with $2<\mathrm{EF}<20$. It is therefore related to gold panning activity.

$\mathrm{Ni}$ is significantly enriched on sites $\mathrm{P} 2$ and $\mathrm{P} 10$ with $5<\mathrm{EF}<20$. Its presence 
Table 4. Enrichment factor (EF) for TME in sediment.

\begin{tabular}{cccccccc}
\hline & As & $\mathrm{Cd}$ & $\mathrm{Cr}$ & $\mathrm{Mn}$ & $\mathrm{Ni}$ & $\mathrm{Pb}$ & $\mathrm{Zn}$ \\
\hline P1 & 0.30 & 0.00 & 0.90 & 1.30 & 1.5 & 0.60 & 0.90 \\
P2 & 15.00 & 0.20 & 1.50 & 4.30 & 12.50 & 1.70 & 0.40 \\
P3 & 0.10 & 0.00 & 0.20 & 0.70 & 0.10 & 0.50 & 71.60 \\
P4 & 1.00 & 0.00 & 0.30 & 1.90 & 0.00 & 1.30 & 51.00 \\
P5 & 0.40 & 0.00 & 0.90 & 9.10 & 1.40 & 0.70 & 0.90 \\
P6 & 1.20 & 0.00 & 0.20 & 5.20 & 1.20 & 1.00 & 6.90 \\
P7 & 0.10 & 0.00 & 0.50 & 3.90 & 0.10 & 0.20 & 34.70 \\
P8 & 0.80 & 0.00 & 0.30 & 8.50 & 0.00 & 2.40 & 45.00 \\
P9 & 0.10 & 0.00 & 0.00 & 0.40 & 0.10 & 0.10 & 0.20 \\
P10 & 13.50 & 0.30 & 1.70 & 0.80 & 6.60 & 1.70 & 46.50 \\
P11 & 1.60 & 0.00 & 0.30 & 5 & 1.70 & 1.00 & 2.20 \\
P12 & 23.10 & 0.00 & 3.10 & 2.60 & 1.90 & 0.10 & 9.90 \\
Minimum & 0.10 & 0.00 & 0.00 & 0.40 & 0.00 & 0.10 & 0.20 \\
Maximum & 23.10 & 0.30 & 3.10 & 9.10 & 12.50 & 2.40 & 71.60 \\
SD & 7.83 & 0.10 & 0.89 & 2.94 & 3.70 & 0.72 & 25.56 \\
Average & 4.77 & 0.04 & 0.83 & 3.64 & 2.26 & 0.94 & 22.52 \\
\hline
\end{tabular}

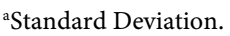

is due to an anthropic activity which is gold panning. Sediments are slightly enriched in $\mathrm{Pb}$, with $\mathrm{EF}<2$. However, gold panning activities resulted in moderate enrichment in some parts of the mine site with an EF $>2$.

It occurs naturally in the sediments but at sites $\mathrm{P} 2$ and $\mathrm{P} 10(\mathrm{EF}>1.5)$ its presence is due to gold panning activity. On-site P8 $(2<\mathrm{EF}<5)$ there is a donation linked to gold panning activity.

The sediments are on the whole weakly enriched $\mathrm{Zn}$ in places, with $\mathrm{EF}<2$, therefore present naturally in the sediments but at site P11 (EF $>1.5$ ). It is moderately to significantly enriched at sites P6, P11, and P12 with $2<\mathrm{EF}<20$. Its presence is due to gold panning activity. It is highly to extremely enriched on sites P3, P4, P7, P8, and P10 with $20<\mathrm{EF}<80$. It is therefore anthropogenic (gold panning activity) on these sites.

\subsubsection{Geo-Accumulation Index (I-geo)}

Table 5 present the results of calculation of the geo-accumulation index (I-geo).

For some ETM, the indices are I-geo $(\mathrm{Cd})<0$, I-geo $(\mathrm{Cr})<0$, I-geo $(\mathrm{Ni})<0$ and I-geo $(\mathrm{Pb})<0$ at all sites. This assumes that there is no pollution concerning these metals. The index $1<\mathrm{I}$-geo (As) $<2$ at the P12 ore processing site shows moderate pollution related to gold panning activity. The index $1<\mathrm{I}$-geo $(\mathrm{Fe})<2$ at the P9 cyanidation site shows moderate pollution. Sites P7 and P8 show slight pollution $(0<\mathrm{I}$-geo $(\mathrm{Mn})<1)$. The index $0<\mathrm{I}$-geo $(\mathrm{Zn})<1$ on sites P6 and P12 show slight pollution. At the cyanidation site P8, $2<\mathrm{I}$-geo $(\mathrm{Zn})<3$ indicates moderate pollution. On the sites of watercourses $\mathrm{P} 4$ and $\mathrm{P} 7$ we have $3<\mathrm{I}$-geo $(\mathrm{Zn})<4$ showing strong pollution. Site $\mathrm{P}$, which is a gold panning site, has an I-geo $(\mathrm{Zn})>5$ index showing extreme pollution.

\subsection{Principal Component Analysis (PCA)}

Table 6 shows the eigenvalues, the percentages of the variances expressed for 
Table 5. Geo-accumulation index (I-geo) of ETM in sediments.

\begin{tabular}{ccccccccc}
\hline & $\mathrm{As}$ & $\mathrm{Cd}$ & $\mathrm{Cr}$ & $\mathrm{Fe}$ & $\mathrm{Mn}$ & $\mathrm{Ni}$ & $\mathrm{Pb}$ & $\mathrm{Zn}$ \\
\hline $\mathrm{P} 1$ & -4.3 & -8.1 & -2.5 & -2.3 & -2 & -1.7 & -3.2 & -2.5 \\
P2 & -1.8 & -7.9 & -5.1 & -5.7 & -3.6 & -2.1 & -4.9 & -7 \\
P3 & -3.1 & -8.9 & -1.9 & 0.1 & 0.2 & -3 & -0.4 & 6.9 \\
P4 & -2.3 & -9.1 & -4.1 & -2.3 & -1.4 & -6.9 & -1.9 & 3.4 \\
P5 & -3.5 & -7.6 & -2.4 & -2.2 & 1 & -1.7 & -2.8 & -2.4 \\
P6 & -2.4 & -7.7 & -4.7 & -2.6 & -0.2 & -2.3 & -2.6 & 0.2 \\
P7 & -4.8 & -7.3 & -2.7 & -1.8 & 0.2 & -5.3 & -4.3 & 3.3 \\
P8 & -3.3 & -9.8 & -4.7 & -3.1 & 0 & -8 & -1.8 & 2.4 \\
P9 & -2.5 & -7.9 & -5.6 & 1.1 & -0.2 & -1.8 & -3 & -1.1 \\
P10 & -1.8 & -7.3 & -4.8 & -5.5 & -5.9 & -2.8 & -4.8 & 0 \\
P11 & -1.7 & -7.9 & -4 & -2.4 & 0 & -1.6 & -2.4 & -1.2 \\
P12 & 1.6 & -7.4 & -1.3 & -3 & -1.5 & -2 & -6.9 & 0.3 \\
\hline
\end{tabular}

Table 6. Eigenvalues and percentage of variances.

\begin{tabular}{cccc}
\hline & F1 & F2 & F3 \\
\hline Eigen Value & 3.00 & 1.87 & 1.26 \\
\% of expressed Variance & 37.56 & 23.34 & 15.69 \\
Cumul Eigen Value & 3.00 & 4.87 & 6.13 \\
Cumul \% of expressed Variance & 37.56 & 60.90 & 76.59 \\
\hline
\end{tabular}

each factor, and the accumulation of these variances. It shows three (3) factors with expressed variances of $37.56 \%$ for factor $1,23.34 \%$ for factor 2 , and $15.69 \%$ for factor F3. Factors F1 and F2, express a variance estimated at $60.90 \%$ allowing to represent in a significant way and explains the interactions and the various phenomena.

Table 7 shows the correlation matrix. Thus there is a correlation between As and $\mathrm{Cr}$ (0.683), between $\mathrm{Cd}$ and $\mathrm{Pb}(-0.695)$, between $\mathrm{Pb}$ and $\mathrm{Zn}$ there is a strong correlation (0.906).

\section{Space of variables in the factorial F1-F2 plane}

The factor F1 (37.56\%) is determined in its positive part by $\mathrm{Cd}(0.731)$ and in its negative part by $\mathrm{Pb}(-0.959)$ and $\mathrm{Zn}(-0.853)$. The grouping of these elements in the negative part indicates that their presence is related to the erosion of mining waste.

The F1 factor therefore expresses the mineralization of anthropogenic origin of the sediments from gold panning activity (Figure 4). The F2 factor (23.34\%) is determined in its positive part by As (0.741) and Cr (0.938). These two elements participate in the composition of the clay phases while they are present in the biosphere. The F2 factor thus expresses the mineralization of the natural origin of the sediments.

\section{Discussion}

The values of the mean contents in surface sediments are mostly higher than their values in unpolluted sediments. However, for elements such as cadmium $(<0.001 \mathrm{mg} / \mathrm{kg})$, chromium $(6.35 \mathrm{mg} / \mathrm{kg})$ and nickel $(5.17 \mathrm{mg} / \mathrm{kg})$ the proportions 
Table 7. Correlation matrix.

\begin{tabular}{ccccccccc}
\hline & $\mathrm{As}$ & $\mathrm{Cd}$ & $\mathrm{Cr}$ & $\mathrm{Fe}$ & $\mathrm{Mn}$ & $\mathrm{Ni}$ & $\mathrm{Pb}$ & $\mathrm{Zn}$ \\
\hline $\mathrm{As}$ & 1 & & & & & & & \\
$\mathrm{Cd}$ & 0.346 & 1 & & & & & & \\
$\mathrm{Cr}$ & 0.683 & 0.205 & 1 & & & & & \\
$\mathrm{Fe}$ & -0.160 & -0.226 & 0.040 & 1 & & & & \\
$\mathrm{Mn}$ & -0.274 & -0.039 & 0.138 & 0.214 & 1 & & & \\
$\mathrm{Ni}$ & 0.191 & 0.385 & 0.149 & 0.103 & 0.093 & 1 & & \\
$\mathrm{~Pb}$ & -0.293 & -0.0695 & 0.165 & 0.492 & 0.312 & -0.282 & 1 & \\
$\mathrm{Zn}$ & -0.128 & -0.416 & 0.378 & 0.526 & 0.184 & -0.251 & 0.906 & 1 \\
\hline
\end{tabular}

Projection des variables sur le plan factoriel $\left(\begin{array}{ll}1 \times & 2\end{array}\right)$

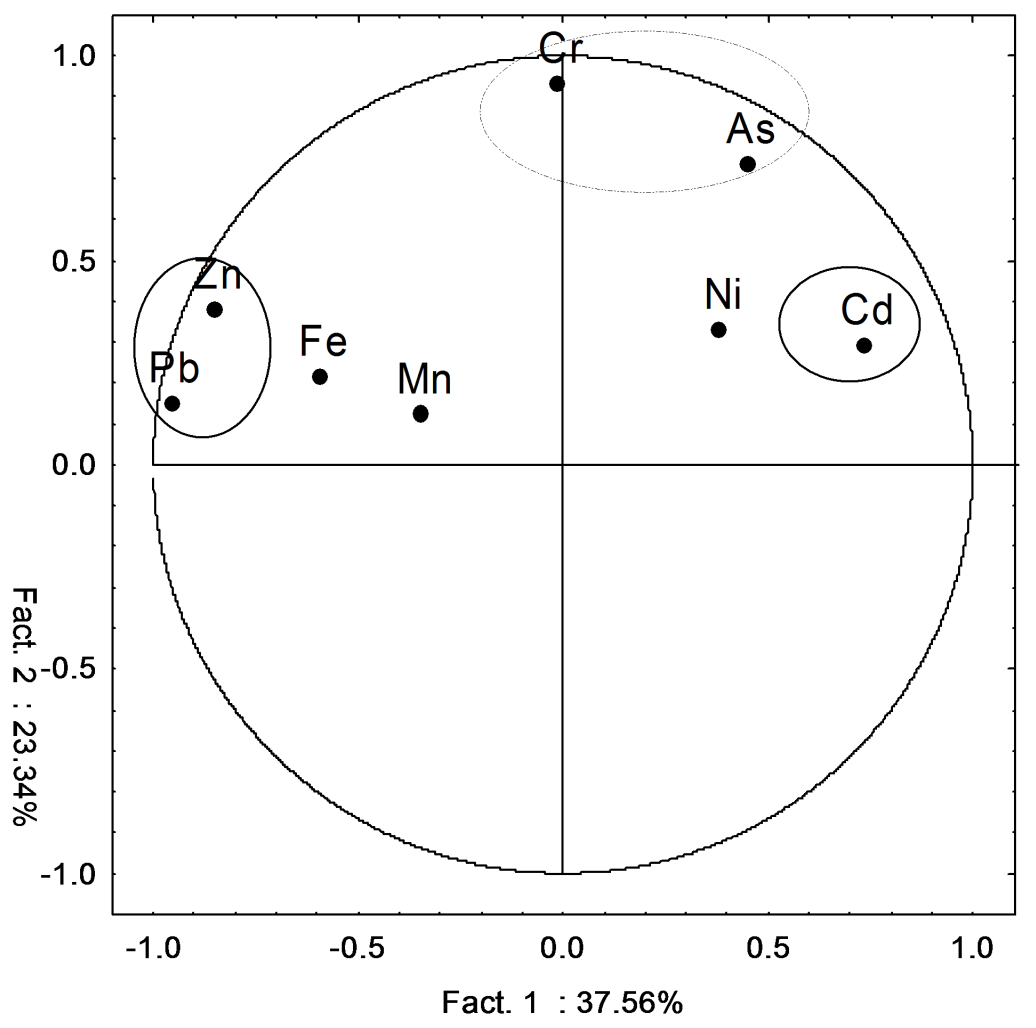

Figure 4. Space of variables in the factorial F1-F2 plane.

are not high. These low levels can be explained by the fact that gold mining does not induce a high production of these trace elements which could contaminate the sediments. Thus, [7] showed that the sediments of Tetrem $(0.35 \mathrm{mg} / \mathrm{kg})$ and Adobewora $(0.57 \mathrm{mg} / \mathrm{kg})$, which are located in Ghana, present below standard values. For arsenic, it should be noted that the $\mathrm{P} 12$ ore processing site $(\mathrm{As}=8.97$ $\mathrm{mg} / \mathrm{kg}$ ) has a high content. This high level is due to the presence of arsenic is generally associated with that of gold, especially as the mine waste contains both elements. Also, erosion-alteration processes of arsenic-rich bedrock favor the formation of contaminated soils. According to [21] [22], anthropogenic sources of arsenic pollution come mainly from mining (gold, copper, lead, cobalt), smelting, fossil fuel combustion, wood preservation, and waste incineration. For 
the trace elements iron $(20583 \mathrm{mg} / \mathrm{kg})$ and manganese $(611.37 \mathrm{mg} / \mathrm{kg})$, concentrations are below the norm in unpolluted sediments, while for zinc (955.86 $\mathrm{mg} / \mathrm{kg}$ ) they exceed the norm in unpolluted sediments [23]. Abnormal values for zinc concentrations could be attributed to the pollutant load from the various discharges from gold panning operations. On mineral extraction and processing sites, certain trace elements contribute to environmental contamination, particularly sediments, are dissolved in solution. In addition to this, there is the burden of the numerous effluents from mining extractions. These elements constitute a danger for sediments, water, living species (plants and animals) and for human health. Indeed on the sites of cyanidation P8 $(421 \mathrm{mg} / \mathrm{kg})$ active cyanidation pond, $\mathrm{P} 9(37.10 \mathrm{mg} / \mathrm{kg})$ and $\mathrm{P} 10(78.01 \mathrm{mg} / \mathrm{kg})$ former cyanidation pond, there is the use of zinc for the recovery of gold contained in waste rock present inside the cyanidation ponds. According to [24], excessive concentrations of TMEs in soils influence the uptake of these elements by plants; as they can be toxic to plants and animals, they can affect agricultural production as well as the sanitary quality of food for human consumption. These results are in agreement with those of [25] that studied the sediments in the vicinity of the Zeïda mine in Morocco and found a high zinc content $(9074 \mathrm{mg} / \mathrm{kg})$ showing the contamination of the sediments.

Using the enrichment factor (EF) as an effective tool to assess the extent of metal contamination in the soil, the EF values for $\mathrm{Cd}(\mathrm{EF}<1), \mathrm{Cr}(\mathrm{EF}<5)$ and $\mathrm{Pb}(\mathrm{EF}<5)$ are very low, showing that there is no contamination of the sediment with these various trace elements. The metals $\mathrm{Cd}, \mathrm{Cr}$, and $\mathrm{Pb}$ cannot be considered as main pollutants. $\mathrm{Ni}(\mathrm{EF}<5)$ and $\mathrm{Mn}(\mathrm{EF}<5)$ in most of the sites show no contamination. However, at P2 ore extraction $(\mathrm{EF}=12.5)$ and cyanide P10 processing sites $(\mathrm{EF}=6.6)$ there is sediment enrichment related to gold panning. Nickel is not considered a major pollutant at these sites. On the other hand, manganese in the Bronzoué River P5 (EF = 9.1), on cyanide treatment P8 (EF = 8.5) and in the Bandama River P6, P7 $(3.9<\mathrm{EF}<5.9)$ shows sediment enrichment. Manganese is observed as a major pollutant at these sites. For arsenic, there is significant enrichment $(\mathrm{EF}>5)$ at the gold panning sites $\mathrm{P} 2(\mathrm{EF}=15)$, $\mathrm{P} 10(\mathrm{EF}=13.5)$ and $\mathrm{P} 12(\mathrm{EF}=23.1)$. This preponderance of arsenic is related to the fact that the mineralized rocks mined often contain arsenopyrite or chalcopyrite.

Indeed, gold mining leads to arsenic contamination of surface sediments. [26] explained the anthropological origin of arsenic by the presence of agricultural activities, mine tailings and associated gold, silver and copper smelters, and atmospheric deposition. It is therefore considered a major pollutant. Zinc is excessively present in most of the surface sediments sampled. At gold panning sites $\mathrm{P} 3(\mathrm{EF}=71), \mathrm{P} 8(\mathrm{EF}=45)$, and $\mathrm{P} 10(\mathrm{EF}=46.5)$ there is high enrichment which could be explained at the P8 and P10 sites by the fact that zinc is used for gold recovery and by leaching from contaminated sites. For sites $\mathrm{P} 4(\mathrm{EF}=51)$ and P7 $(\mathrm{EF}=34.7)$, which are surface water sediments, this zinc contamination is primarily related to the drainage of mine tailings to surrounding watercourses. Zinc 
is then considered a major pollutant.

Furthermore, the geo-accumulation index (I-geo) shows that there is no pollution in $\mathrm{Cd}, \mathrm{Cr}, \mathrm{Fe}, \mathrm{Mn}, \mathrm{Ni}$, and $\mathrm{Pb}$ with I-geo $<1$ at all sites except for sites $\mathrm{P} 9$ and $\mathrm{P} 5$ for $\mathrm{Fe}$ and $\mathrm{Mn}$. Also on site $\mathrm{P} 9 \mathrm{I}-\mathrm{geo}(\mathrm{Fe})=1.1$ translating moderate pollution into iron and on-site P5.

I-geo $(\mathrm{Fe})=1.1$ translating slight pollution into manganese. But I-geo of arsenic $>1$ at the P12 treatment site $(\mathrm{I}-\mathrm{geo}(\mathrm{As})=1.6)$. This occurrence of the trace element zinc is also highlighted by the results of the geoaccumulation index (I-geo) calculations, which confirm the anthropogenic action with an I-geo $>3$ for zinc on most gold panning sites and even in watercourses. These results show that the sediments of the mining sites are polluted in zinc (P3 and P8) compared to those of the sites distant from the mines (P4 and P7). In this case, this would be harmful to the health of the local population because this risk is associated with land use (plant consumption) and water consumption.

These results are similar to those of [27] that studied the contamination of surface water and sediments in the Val de Milluni with trace metal elements by mining waste.

Principal Component Analysis (PCA) was carried out on the physico-chemical data to determine the origin of in surface sediments. It shows that $\mathrm{Cd}, \mathrm{Pb}$, and $\mathrm{Zn}$ are of anthropogenic origin and therefore linked to gold panning activity.

According to the work of [6] at the SOMIAF mine site in the Aboisso region of Côte d'Ivoire, mining activities are the source of sediment contamination by $\mathrm{Pb}$.

$\mathrm{Cd}$ is very often present in $\mathrm{Zn}$ mineralization, the main mineral occurrence of which is sphalerite [28]. In the Study Area, As and Cr have a natural origin in surface sediments. Arsenic present in the sediments is essential of geological origin and therefore natural. Furthermore, the geological formations encountered in the region are essentially magmatic (schists and granodiorites). Indeed, the geological origin of the arsenic-rich rock formation is a predominant reason for arsenic contamination of soils and water [29].

\section{Conclusion}

The study carried out at the artisanal gold mining sites of Kokumbo allows the level of contamination of surface sediments to be determined from their content of MTEs and also to identify the sources of sediment contamination. The results show that the levels of MTEs such as As, Mn, and $\mathrm{Zn}$ in the sediments are very high compared to their content limit in unpolluted sediments. In terms of level of contamination, the enrichment factor (EF) and the geo-accumulation index (I-geo) show a high enrichment and pollution of As at site P12, Mn at sites P5, $\mathrm{P} 7$ and $\mathrm{Zn}$ at gold panning sites (P3, P8, P10) and waterways (P4 and P7), reflecting an anthropogenic origin linked to gold panning activity for $\mathrm{Zn}$. As for the PCA, it showed that As is of natural origin and $\mathrm{Zn}$ results from gold panning activity. Surface sediments are contaminated with As and Zn. They present a 
potential risk to the health of the populations, aquatic and wildlife species of the Kokumbo sub-prefecture. To this end, measures must be taken to reduce the potential impact to avoid contaminating water resources, particularly the Bandama River.

\section{Acknowledgements}

We thank the administrative authorities of Kokumbo, the chiefs of the customary communities and the gold panners for allowing us to sample in his constituency. We also thank the MINERWA International Mixed Laboratory for its logistical support in carrying out this study.

\section{Conflicts of Interest}

The authors declare no conflicts of interest regarding the publication of this paper.

\section{References}

[1] Razo, I., Carrizales, L., Castro, J., Díaz-Barriga, F. and Monroy, M. (2004) Arsenic and Heavy Metal Pollution of Soil, Water and Sediments in a Semi-Arid Climate Mining Area in Mexico. Water Air Soil Pollution, 152, 129-152. https://doi.org/10.1023/B:WATE.0000015350.14520.c1

[2] Wandan, E.N., Koffi, G.B., Kouadio, K.B. and Gomba, Z.D. (2015) Environmental Evaluation of Small Scale Gold Mining in the Bounkani Region in the Upper East Area of Côte d'Ivoire. International Journal of Environmental Monitoring and Analysis, 3, 265-274. https://doi.org/10.11648/j.ijema.20150305.14

[3] Programme National de Rationalisation de L'orpaillage n Côte D'ivoire (PNRO) (2013) Ministère de l'Industrie et des Mines.

[4] Loko, S., Ahoussi, K.E., Koffi, Y.B., Kakou, N.F., Kouassi, A.M. and Biemi, J. (2013) Microbiological and Physico-Chemical Quality of Groundwater from Artisanal Sites of Mining Exploitation in the South-West of Côte d'Ivoire: Case of the Area of Hiré. International Journal of Scientific \& Engineering Research, 4, 567-574.

[5] Yapi, Y.H.A., Dongui, B.K., Trokourey, A., Barima, Y.S.S., Essis, Y. and Atheba, P. (2014) Evaluation de la pollution métallique des eaux souterraines et de surface dans un environnement minier aurifère à Hiré (Côte d'Ivoire). International Journal of Biological and Chemical Sciences, 8, 1281-1289.

https://doi.org/10.4314/ijbcs.v8i3.41

[6] Yao, K.A.F., Salze, D., Lopez-Ferber, M., Lasm, T. and Belcourt, O. (2017) Impact of an Abandoned Mine on Surrounding Soils, Surface Water and Stream Sediment: Case of SOMIAF Gold Mine, Côte d'Ivoire. International Journal of Environmental Science and Development, 8, 323-343. https://doi.org/10.18178/ijesd.2017.8.9.1031

[7] Agyarko, K., Dartey, E., Kuffour, A.R. and Sarkodie, A.P. (2014) Assessment of Trace Elements Levels in Sediment and Water in Some Artisanal and Small-Scale Mining (ASM) Localities in Ghana. Current World Environment, 9, 7-16. https://doi.org/10.12944/CWE.9.1.02

[8] Institut Nationale De La Statistique (2014) Recensement Général de la Population et de l'Habitat (RGPH). Données socio démographiques et économiques, Région du Bélier, 31-60.

[9] Chauveau, J.P. (1979) Les cadres socio-historiques de la production dans la région 
de Kokumbo (pays baoulé, Côte d'Ivoire). Cahier ORSTOM sciences humaines, Bondy, 7.

[10] Avenard, J.M., Eldln, M., Girard, G., Sircoulon, J., Touchebeuf, P., Guillaumet, J.L., Adjanohoun, E. and Perraud, A. (1971) Le Milieu naturel de la Côte d'Ivoire. Mémoires ORSTOM, 50, 339.

[11] N'go, Y.A., Gone, D.L., Savane, I. and Goble, M.M. (2005) Potentialités en eaux souterraines des aquifères de la région d'Agboville (Sud-Ouest de la Côte d'Ivoire): Caractérisation hydroclimatique et physique. Africa Science, 1, 127-144. https://doi.org/10.4314/afsci.v1i1.35401

[12] Yao, K.A., Kouassi, A.M., Koffi, Y.B. and Biemi, J. (2010) Caractérisation hydrodynamique et hydrogéochimique des aquifères fissurés de la région de Toumodi (centre de la Côte d'Ivoire). Journal of Environmental Hydrology, 18, 455-470.

[13] Daouda, Y.B. (1998) Lithostratigraphie et pétrographie des formations birimiennes de Toumodi-Fêtêkro (Côte d'Ivoire). Implication pour l'évolution crustale du paléoprotérozoique du craton ouest africain. Thèse de Doctorat de l'Université d'Orléans, $195 \mathrm{p}$.

[14] Reimann, C. and Caritat, P.D. (2005) Distinguishing between Natural and Anthropogenic Sources for Elements in the Environment: Regional Geochemical Surveys versus Enrichment Factors. Science of the Total Environment, 337, 91-107. https://doi.org/10.1016/j.scitotenv.2004.06.011

[15] Sutherland, R.A. (2000) Bed Sediment Associated Trace Metals in an Urban Stream, Oahu, Hawaii. Environmental Geology, 39, 611-637. https://doi.org/10.1007/s002540050473

[16] Wedepohl, K.H. (1995) The Composition of Continental Crust. Goechimica and Cocmochimica Acta, 7, 1217-1232. https://doi.org/10.1016/0016-7037(95)00038-2

[17] Müller, G. (1969) Index of Geoaccumulation in Sediments of the Rhine River. Geojournal, 2, 109-118.

[18] Guillen, M.T., Delgado, J., Albanese, S., Jose Miguel Nieto, J.M., Lima, A. and De Vivo, B. (2012) Heavy Metals Fractionation and Multivariate Statistical Techniques to Evaluate the Environmental Risk in Soils of Huelva Township (SW Iberian Peninsula). Journal of Geochemical Exploration, 119-120, 32-43. https://doi.org/10.1016/j.gexplo.2012.06.009

[19] Benrejdal, F., Haddad, H. and Ghoualem, H. (2018) Contribution à l'analyse physico-chimique des eaux de ruissellement urbaines. Algerian Journal of Environmental Science and Technology, 4, 57-61.

[20] Nasri, B., Benatiallah, A., Kalloum, S. and Benhamza, M. (2018) Caractérisation physico-chimique des eaux souterraines de la région de kenadsa et Galbelaouda (sud-ouest de l'Algérie). Algerian Journal of Environmental Science and Technolo$g y, 4,82-93$.

[21] Wang, S. and Mulligan, C. (2006) Effect of Natural Organic Matter on Arsenic Release from Soils and Sediments into Groundwater. Environmental Geochemistry and Health, 28, 197-214. https://doi.org/10.1007/s10653-005-9032-y

[22] Wang, S. and Mulligan, C. (2009) Effect of Natural Organic Matter on Arsenic Mobilization from Mine Tailings. Journal of Hazardous Materials, 168, 721-726. https://doi.org/10.1016/j.jhazmat.2009.02.088

[23] Calamari, D. and Naeve, H. (1994) Revue de la pollution dans l'environnement aquatique africain. Document Technique du CPCA, FAO, Rome, 25.

[24] Lee, C.G., Chon, H.T. and Jung, M.C. (2001) Heavy Metal Contamination in the 
Vicinity of the Daduk Au-Ag-Pb-Zn Mine in Korea. Applied Geochemistry, 16, 1377-1386. https://doi.org/10.1016/S0883-2927(01)00038-5

[25] El Hachimi, M.L., Fekhaoui, M., El Abidi, A. and Rhoujatti, A. (2014) Contamination des sols par les métaux lourds à partir de mines abandonnées: Le cas des mines Aouli-Mibladen-Zeïda au Maroc. Cahiers Agricultures, 23, 213-219. https://doi.org/10.1684/agr.2014.0702

[26] Smedley, P.L. and Kinniburgh, D. (2001) A Review of the Source, Behaviour and Distribution of Arsenic in Natural Waters. Applied Geochemistry, 17, 517-568. https://doi.org/10.1016/S0883-2927(02)00018-5

[27] Salvarredy, M. (2008) Contamination en métaux lourds des eaux de surface et des sédiments du Val de Milluni (Andes Boliviennes) par des déchets miniers: Approches géochimique, minéralogique et hydrochimique. Thèse de Doctorat, Université de Toulouse, Toulouse.

[28] OECD (1996) Sources of Cadmium in the Environment. OECD Publishing, Paris.

[29] Smedley, P.L. and Kinniburgh, D.G. (2002) A Review of the Source, Behaviour and Distribution of Arsenic in Natural Waters. Applied Geochemistry, 17, 517-568. https://doi.org/10.1016/S0883-2927(02)00018-5 